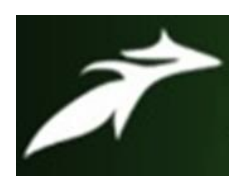

Yalla Meera et al, International Journal of Advances in Agricultural Science and Technology,

Vol.8 Issue.9, September-2021, pg. 155-162

ISSN: 2348-1358

Impact Factor: 6.057

NAAS Rating: 3.77

\title{
CONSTRAINTS FACED BY THE RESPONDENTS IN AVAILING THE BENEFITS OF DWCRA IN SRIKAKULAM DISTRICT OF ANDHRA PRADESH
}

\author{
Yalla Meera $^{1}$; Dipak Kumar Bose ${ }^{2}$; Syed H.Mazhar ${ }^{3}$; Jahanara ${ }^{4}$ \\ ${ }^{1}$ M.Sc.Ag (Extension and Communication), Final Semester, SHUATS (Prayagraj) \\ ${ }^{2 \& 3}$ Associate Professor, Department of Agricultural Extension and Communication, SHUATS (Prayagraj) \\ ${ }^{4}$ Professor and Head, Department of Agricultural Extension and Communication, SHUATS (Prayagraj) \\ Author's e-mail: meerakrishnayalla@gmail.com \\ DOI: 10.47856/ijaast.2021.v08i9.017
}

\begin{abstract}
Women and Children constitute 67.7 per cent of the country's total population as per the census 2001 . Women exclusively accounted for million constituting 48.3 percent of the country's population. By virtue of these figures, they shall be considered as an important target group. Hence, it becomes an essentiality to empower women economically and socially for promoting national development. Development of Women and Children in Rural Areas (DWCRA) was launched as sub scheme of IRDP. It was initially started as pilot project in 50 selected districts in all states during 1982- 1983. During, the IX plan almost all state governments started implementing DWCRA activities in rural areas. The objectives of this programme are to organize women into socio-economic activity groups with the dual purpose of providing self- employment opportunities and social strength to them. Besides, providing financial support for income generating activities, DWCRA also increases women's access to basic services of health, education, children's nutrition, safe drinking water, sanitation and environment. Though there are many achievements to its credit, still there is wider space to accommodate many innovative ideas elicited through the participation of women over the years for improving the programme periphery.
\end{abstract}

\section{Introduction}

Development of Women and Children in Rural Areas (DWCRA) was launched as sub scheme of IRDP. It was initially started as pilot project in 50 selected districts in all states during 1982- 1983. During, the IX plan almost all state governments started implementing DWCRA activities in rural areas. DWCRA programme was introduced with the financial assistance from UNICEF to strengthen the women's component of poverty alleviation programmes.

The objectives of DWCRA scheme are to improve economic health, education and social status of rural women by providing the required income generating activities to earn their livelihood. This can be attained through specific objectives like improving the existing economic activities of the rural women by generating employment opportunities and also improving the quality of life of rural women and their children, providing supportive services to enable the rural women to improve their economic conditions through the existing skills and locally available resources, providing suitable training in productive skills for the DWCRA beneficiaries, providing suitable marketing facilities and empowering the rural women to 


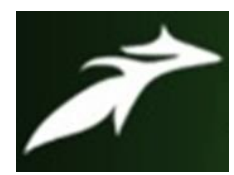

Yalla Meera et al, International Journal of Advances in Agricultural Science and Technology,

Vol.8 Issue.9, September-2021, pg. 155-162

ISSN: 2348-1358

Impact Factor: 6.057

NAAS Rating: 3.77

take collective decisions in popularizing their finished products in the market, providing better care for the children of DWCRA groups in health, nutrition, environment and education.

The main objectives of the study were to find out the socio-economic profile of the respondents, several constraints faced by the respondents like activities related to income generation, input supply, cooperation among them, trainings received, market facilities, etc. Suggestions provided by them to overcome the constraints.

\section{Research Methodology}

The state of Andhra Pradesh was selected for the study purposively as the investigator is familiar with the local language which would help to build quick rapport and also facilitates in depth study through personal observation. More over number of DWCRA groups are more in Andhra Pradesh. Descriptive research design is adopted for the present study. Descriptive research is used to describe the characteristics of a population or phenomenon being studied. No variables are under the control of researcher as the study is to report the situation as it is. It was adopted since the DWCRA programme was already implemented in the area and no other design will fit keeping in view the objectives of the study. Srikakulam was purposively selected since it is one of the district in Andhra Pradesh where the DWCRA programme is under implementation from the inception of i.e. 1983 and has highest number of DWCRA groups. Out of 38 blocks in Srikakulam, Narasannapeta block is selected through purposive sampling. In Narasanapeta block, out of 43 villages, 6 villages were purposively selected. The selected villages were Makivalasa, Devadi, Killam, Komarthy, Madapam and Gopalapenta. Ten DWCRA groups were selected purposively from each of the selected 6 villages. From each DWCRA group, two women beneficiary was selected randomly. Thus, constitutes 20 women beneficiaries from each village of ten DWCRA group and makes it to 120 women beneficiaries from 6 villages. Each DWCRA group woman was interviewed personally in local language i.e. telugu by the investigator and the responses were recorded on interview schedule immediately. 


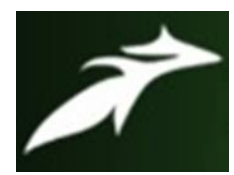

Yalla Meera et al, International Journal of Advances in Agricultural Science and Technology,

Vol.8 Issue.9, September-2021, pg. 155-162

ISSN: 2348-1358

Impact Factor: 6.057

NAAS Rating: 3.77

\section{Results and Demonstration}

Table 1: Socio-economic profile of the respondents $(N=120)$

\begin{tabular}{|c|c|c|c|c|}
\hline Sl.No. & Characteristics & Category & Frequency & Percentage \\
\hline \multirow[t]{3}{*}{1} & \multirow[t]{3}{*}{ Age ( in years) } & Young $(<35)$ & 43 & 35.83 \\
\hline & & Middle (36-50) & 53 & 44.17 \\
\hline & & Old $(>50)$ & 24 & 20.00 \\
\hline \multirow[t]{7}{*}{2} & \multirow[t]{7}{*}{ Education } & Illiterate & 14 & 11.67 \\
\hline & & Functionally literate & 17 & 14.17 \\
\hline & & Primary school & 9 & 7.5 \\
\hline & & Middle school & 15 & 12.5 \\
\hline & & High school & 30 & 25 \\
\hline & & Intermediate & 23 & 19.17 \\
\hline & & Graduate & 12 & 10 \\
\hline \multirow[t]{3}{*}{3} & \multirow[t]{3}{*}{ Family size } & Small (1-3 members) & 51 & 42.5 \\
\hline & & Medium (4-6 members) & 44 & 36.67 \\
\hline & & Large (7-9 members) & 25 & 20.83 \\
\hline \multirow[t]{3}{*}{4} & \multirow[t]{3}{*}{ Socio-economic status } & Low & 43 & 35.83 \\
\hline & & Medium & 51 & 42.5 \\
\hline & & High & 26 & 21.67 \\
\hline \multirow[t]{3}{*}{5} & \multirow[t]{3}{*}{ Income generation } & Low & 43 & 35.83 \\
\hline & & Medium & 59 & 49.17 \\
\hline & & High & 18 & 15 \\
\hline
\end{tabular}




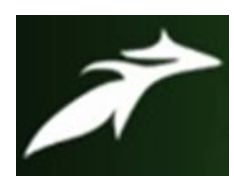

Yalla Meera et al, International Journal of Advances in Agricultural Science and Technology, Vol.8 Issue.9, September-2021, pg. 155-162

ISSN: 2348-1358

Impact Factor: 6.057

NAAS Rating: 3.77

\begin{tabular}{|c|c|c|c|c|}
\hline \multirow[t]{2}{*}{6} & \multirow[t]{2}{*}{ Training received } & Yes & 67 & 55.83 \\
\hline & & No & 53 & 44.17 \\
\hline \multirow[t]{3}{*}{7} & \multirow[t]{3}{*}{ Innovativeness } & Low & 46 & 38.33 \\
\hline & & Medium & 52 & 43.33 \\
\hline & & High & 22 & 18.33 \\
\hline \multirow[t]{3}{*}{8} & \multirow[t]{3}{*}{ Risk orientation } & Low & 27 & 22.50 \\
\hline & & Medium & 70 & 58.33 \\
\hline & & High & 23 & 19.17 \\
\hline \multirow[t]{3}{*}{9} & \multirow[t]{3}{*}{ Market orientation } & Low & 32 & 26.67 \\
\hline & & Medium & 65 & 54.17 \\
\hline & & High & 23 & 19.17 \\
\hline \multirow[t]{3}{*}{10} & \multirow[t]{3}{*}{ Knowledge level } & Low & 37 & 30.83 \\
\hline & & Medium & 55 & 45.83 \\
\hline & & High & 28 & 23.33 \\
\hline
\end{tabular}

From table 1, it can be understood that majority of the women beneficiaries belong to middle age (44.17\%), followed by young age (35.83\%) and old age (20\%). Majority of the women beneficiaries were educated upto high school (25\%), 19.17 percent were educated upto intermediate, 14.17 percent upto functionally literate, 12.5 per cent upto middle school, 11.67 per cent upto illiterate, 10 percent were graduated and 7.5 per cent upto primary school. 42.5 percent of the respondents had small family (1-3 members), followed by 36.67 percent of the respondents had medium family (4-6 members) and 20.83 percent of the respondents had large sized family. 42.5 percent of the women beneficiaries had medium level of socio-economic status, followed by 35.83 percent had low socio-economic status and 21.67 percent had high socio-economic status. This might be because of that medium level of annual income, medium level of material possession, house holdings.

Nearly half of the women beneficiaries (49.17\%) had medium level of annual income, 35.83 per cent had low level of annual income, 15 per cent had high level of annual income. More than 


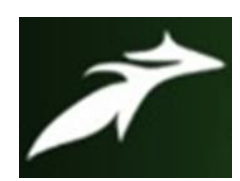

Yalla Meera et al, International Journal of Advances in Agricultural Science and Technology,

Vol.8 Issue.9, September-2021, pg. 155-162

ISSN: 2348-1358

Impact Factor: 6.057

NAAS Rating: 3.77

half of the respondents (55.83\%) received training and the remaining 44.17 per cent of the respondents didn't receive any training. 43.33 per cent of the respondents had medium level of innovativeness, followed by 38.33 per cent of the respondents had low level of innovativeness and 18.33 per cent of women beneficiaries had high level of innovativeness. More than half of the women beneficiaries had medium level of risk orientation $(58.33 \%)$, followed by low level of risk orientation $(22.50 \%)$ and high level of risk orientation $(19.17 \%)$. More than half of the women beneficiaries had medium level of market orientation $(54.17 \%)$, followed by low level of market orientation (26.67\%) and high market orientation (19.17\%). Nearly half of the women beneficiaries $(45.83 \%)$ had medium level of knowledge in functioning of DWCRA, followed by 30.83 per cent of low level of knowledge and 23.33 per cent had high level of knowledge.

Table 2: Constraints faced by the beneficiaries of DWCRA (N=120)

\begin{tabular}{|c|c|c|c|c|}
\hline Sl.No & Constraints & Frequency & Percentage & Rank \\
\hline 1 & Insufficient loan amount & 45 & 37.50 & V \\
\hline 2 & Procedural delay in obtaining the loan amount & 78 & 65.00 & $\mathrm{I}$ \\
\hline 3 & Repayment of loan amount & 23 & 19.16 & $\mathrm{XV}$ \\
\hline 4 & Illiteracy of the group members & 27 & 22.50 & XIII \\
\hline 5 & $\begin{array}{l}\text { Lack of co-operation among the group } \\
\text { members }\end{array}$ & 14 & 11.66 & XVII \\
\hline 6 & $\begin{array}{l}\text { Lack of supervision/ guidance by } \\
\text { organizational officials }\end{array}$ & 36 & 30.00 & VIII \\
\hline 7 & $\begin{array}{l}\text { Inadequate training programmes related to } \\
\text { income generating activity }\end{array}$ & 38 & 31.66 & VII \\
\hline 8 & $\begin{array}{l}\text { Lack of new skills for carrying out the } \\
\text { activity }\end{array}$ & 29 & 24.16 & XII \\
\hline 9 & $\begin{array}{l}\text { Traditional methods to perform the income } \\
\text { generating activity }\end{array}$ & 33 & 27.50 & IX \\
\hline 10 & $\begin{array}{l}\text { Lack of Awareness about income generating } \\
\text { activities }\end{array}$ & 30 & 25.00 & XI \\
\hline 11 & Inadequate supply of inputs & 15 & 12.50 & XVI \\
\hline 12 & Non availability of inputs & 24 & 20.00 & XIV \\
\hline 13 & High cost of inputs & 62 & 51.66 & III \\
\hline 14 & Poor transport facilities & 32 & 26.66 & $\mathrm{X}$ \\
\hline 15 & Poor marketing facilities & 66 & 55.00 & II \\
\hline 16 & Lack of market demand for produced items & 41 & 34.16 & VI \\
\hline 17 & Lack of remunerative price for the produce & 57 & 47.50 & IV \\
\hline
\end{tabular}




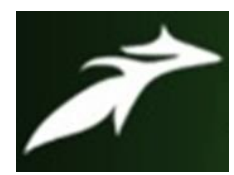

Yalla Meera et al, International Journal of Advances in Agricultural Science and Technology,

Vol.8 Issue.9, September-2021, pg. 155-162

ISSN: 2348-1358

Impact Factor: 6.057

NAAS Rating: 3.77

From table 2, it can be seen that majority of the respondents felt procedural delay in obtaining the loan amount $(65.00 \%)$ secured $1^{\text {st }}$ rank, followed by poor marketing facilities $(55.00 \%)$, high cost of inputs (51.66\%), lack of remunerative price for the produce $(47.50 \%)$, insufficient loan amount $(37.50 \%)$, lack of market demand for produced items $(34.16 \%)$, inadequate training programmes related to income generating activity (31.66\%), lack of supervision / guidance by organization officials (30\%), traditional methods to perform the income generation activity (27.50\%), poor transport facilities (26.66\%), lack of awareness about income generating activities $(25 \%)$, illiteracy of the group members $(22.50 \%)$, non-availability of inputs $(20 \%)$, repayment of loan amount (19.16\%), inadequate supply of inputs $(12.50 \%)$, lack of co-operation among the group members $(11.66 \%)$ secured $2^{\text {nd }}, 3^{\text {rd }}, 4^{\text {th }}, 5^{\text {th }}, 6^{\text {th }}, 7^{\text {th }}, 8^{\text {th }}, 9^{\text {th }}, 10^{\text {th }}, 11^{\text {th }}, 12^{\text {th }}, 13^{\text {th }}, 14^{\text {th }}, 15^{\text {th }}$, $16^{\text {th }}$ and $17^{\text {th }}$ rank respectively.

Table 3. Suggestions given by the beneficiaries to overcome the constraints experienced by them $(\mathrm{N}=120)$

\begin{tabular}{|c|c|c|c|c|}
\hline Sl.No. & Suggestions & Frequency & Percentage & Rank \\
\hline 1 & Provision of sufficient loan Amount & 54 & 45.00 & IV \\
\hline 2 & Timely provision of loan amount & 83 & 69.16 & $\mathrm{I}$ \\
\hline 3 & $\begin{array}{l}\text { Promoting co-operation among } \\
\text { the group members }\end{array}$ & 7 & 5.83 & $\mathrm{XV}$ \\
\hline 4 & $\begin{array}{l}\text { Provision of supervision/ } \\
\text { guidance by organizational officials }\end{array}$ & 52 & 43.33 & V \\
\hline 5 & $\begin{array}{l}\text { Conduct of training programmes } \\
\text { related to income generating activity }\end{array}$ & 27 & 22.50 & VIII \\
\hline 6 & $\begin{array}{l}\text { Imparting new skills to carry } \\
\text { out the activity }\end{array}$ & 25 & 20.83 & IX \\
\hline 7 & $\begin{array}{l}\text { Adoption of modern methods } \\
\text { to perform the activity }\end{array}$ & 18 & 15.00 & XIV \\
\hline 8 & $\begin{array}{l}\text { Creating Awareness about } \\
\text { income generating activities }\end{array}$ & 30 & 25.00 & VII \\
\hline 9 & Adequate supply of inputs & 19 & 15.83 & XIII \\
\hline 10 & Timely provision of inputs & 23 & 19.16 & $\mathrm{X}$ \\
\hline
\end{tabular}




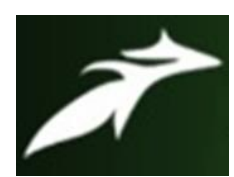

Yalla Meera et al, International Journal of Advances in Agricultural Science and Technology, Vol.8 Issue.9, September-2021, pg. 155-162

ISSN: 2348-1358

Impact Factor: 6.057

NAAS Rating: 3.77

\begin{tabular}{|c|c|c|c|c|}
\hline 11 & Reduction of cost of inputs & 22 & 18.33 & XI \\
\hline 12 & $\begin{array}{l}\text { Provision of better transport } \\
\text { Facilities }\end{array}$ & 20 & 16.66 & XII \\
\hline 13 & $\begin{array}{l}\text { Provision of better marketing } \\
\text { Facilities }\end{array}$ & 72 & 60.00 & II \\
\hline 14 & $\begin{array}{l}\text { Creation of market demand to } \\
\text { produced items }\end{array}$ & 44 & 36.66 & VI \\
\hline 15 & $\begin{array}{l}\text { Provision of remunerative price } \\
\text { to the produce }\end{array}$ & 65 & 55.00 & III \\
\hline
\end{tabular}

From table 3, it can be understood that among the various suggestions offered by the women beneficiaries, timely provision of loan amount (63.16) secured $1^{\text {st }}$ rank, followed by provision of better marketing facilities $(60 \%)$, provision of remunerative price to the produce (55\%), provision of sufficient loan amount (45\%), provision of supervision/ guidance by organizational officials $(43.33 \%)$, creation of market demand to produced items $(36.66 \%)$, creating awareness about income generating activities (25\%), conduct of training programmes related to income generating activity (22.50\%), imparting new skills to carryout the activity $(20.83 \%)$, timely provision of inputs (19.16\%), reduction of cost of inputs (18.33\%), provision of better transport facilities (16.66\%), adequate supply of inputs (15.83\%), adoption of modern methods to perform the activity $(15 \%)$, promoting co-operation among the group members $(5.83 \%)$ secured $2^{\text {nd }}, 3^{\text {rd }}, 4^{\text {th }}, 5^{\text {th }}, 6^{\text {th }}, 7^{\text {th }}$, $8^{\text {th }}, 9^{\text {th }}, 10^{\text {th }}, 11^{\text {th }}, 12^{\text {th }}, 13^{\text {th }}, 14^{\text {th }}, 15^{\text {th }}$ respectively.

\section{Conclusion}

From the study, it can be concluded that majority of the respondents were middle aged(44.17\%), high school education(25\%), small family size(42.5\%), medium socio-economic status(42.5\%), medium income generation(49.17\%), medium innovativeness(43.33\%), medium risk orientation(58.33\%), medium market orientation(54.17\%), medium knowledge level(45.83\%). Most of them had received training $(55.83 \%)$.

Majority of the respondents felt procedural delay in obtaining the loan amount $(65.00 \%)$ secured $1^{\text {st }}$ rank, followed by poor marketing facilities (55.00\%), high cost of inputs $(51.66 \%)$, lack of remunerative price for the produce $(47.50 \%)$, insufficient loan amount (37.50\%), lack of market demand for produced items $(34.16 \%)$, inadequate training programmes related to income generating activity $(31.66 \%)$, lack of supervision / guidance by organization officials (30\%), traditional methods to perform the income generation activity (27.50\%), poor transport facilities (26.66\%), lack of awareness about income generating activities (25\%), illiteracy of the group members (22.50\%), nonavailability of inputs (20\%), repayment of loan amount (19.16\%), inadequate supply of inputs 


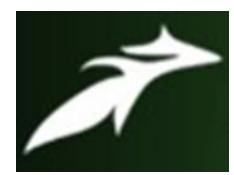

Yalla Meera et al, International Journal of Advances in Agricultural Science and Technology,

Vol.8 Issue.9, September-2021, pg. 155-162

ISSN: 2348-1358

Impact Factor: 6.057

NAAS Rating: 3.77

$(12.50 \%)$, lack of co-operation among the group members $(11.66 \%)$ secured $2^{\text {nd }}, 3^{\text {rd }}, 4^{\text {th }}, 5^{\text {th }}, 6^{\text {th }}, 7^{\text {th }}$, $8^{\text {th }}, 9^{\text {th }}, 10^{\text {th }}, 11^{\text {th }}, 12^{\text {th }}, 13^{\text {th }}, 14^{\text {th }}, 15^{\text {th }}, 16^{\text {th }}$ and $17^{\text {th }}$ rank respectively.

Among the various suggestions offered by the women beneficiaries, timely provision of loan amount (63.16) secured $1^{\text {st }}$ rank, followed by provision of better marketing facilities $(60 \%)$, provision of remunerative price to the produce $(55 \%)$, provision of sufficient loan amount $(45 \%)$, provision of supervision/ guidance by organizational officials $(43.33 \%)$, creation of market demand to produced items (36.66\%), creating awareness about income generating activities (25\%), conduct of training programmes related to income generating activity (22.50\%), imparting new skills to carryout the activity (200.83\%), timely provision of inputs (19.16\%), reduction of cost of inputs (18.33\%), provision of better transport facilities (16.66\%), adequate supply of inputs (15.83\%), adoption of modern methods to perform the activity $(15 \%)$, promoting co-operation among the group members $(5.83 \%)$ secured $2^{\text {nd }}, 3^{\text {rd }}, 4^{\text {th }}, 5^{\text {th }}, 6^{\text {th }}, 7^{\text {th }}, 8^{\text {th }}, 9^{\text {th }}, 10^{\text {th }}, 11^{\text {th }}, 12^{\text {th }}, 13^{\text {th }}, 14^{\text {th }}, 15^{\text {th }}$ respectively.

\section{References}

[1]. Bindu Sharma (2001) Participation of tribal women in income generating activities in Ranchi district of Bihar. M.Sc(Ag).Thesis, Acharya N G Ranga Agricultural University, Hyderabad.

[2]. Mahajan, S. (2013). Women entrepreneurship in india. Global Journal of Management and Business Studies, 3(10), 1143-1148.

[3]. Pallavi I 2006 A study on empowerment of tribal women in Khammam district of Andhra Pradesh. M.Sc(Ag). Thesis, Acharya N G Ranga Agricultural University, Hyderabad.

[4]. Rojarani B 2000 Employement generation,income and expenditure pattern of DWCRA beneficiary families in Kurnool District of Andhra Pradesh. M.Sc(Ag). Thesis, Acharya N G Ranga Agricultural University, Hyderabad.

[5]. Sharma D D and Sharma Anju 2000 DWCRA in Solan (H.P) Performance, problems and suggestions. Rural India 63(2): 56-60.

[6]. Suneetha B (2004) Preference knowledge and opinion of young rural women about selfemployment in Visakhapatnam district of Andhra Pradesh. M.Sc(Ag). Thesis, Acharya N G Ranga Agricultural University, Hyderabad. 